УДК 316.42

\title{
ФЕНОМЕНОЛОГИЧЕСКАЯ ПРИРОДА ВЗАИМООБУСЛОВЛЕННОСТИ ЭКОНОМИЧЕСКОЙ КОНКУРЕНТОСПОСОБНОСТИ И СОЦИАЛЬНОГО КАПИТАЛА БЕЛАРУСИ И УКРАИНЫ*
}

\author{
С.Ю. СОЛОДОВНИКОВ \\ д-р экон. Наук, заведующий кафедрой «Экономика и право» \\ Белорусского национального технического университета, г. Минск
}

\begin{abstract}
Аннотация
Раскрыты сущность и социально-экономические механизмы взаимообусловленности экономической конкурентоспособности и социального капитала Беларуси и Украины. Это позволило предложить пути улучшения использования имеющегося социального капитала в Республике Беларусь для обеспечения устойчивого экономического роста, в том числе: обеспечение равномерного распределения социального капитала в стране на разных социальных горизонтах; совершенствовать систему, препятствующую присвоению социального капитала, накопленного на уровне общества, национальной бюрократией; продолжать развивать механизмы партнерства общества-государства-бизнеса.
\end{abstract}

Abstract

There are revealed essence and the socio-economic interdependence of the mechanisms of economic competitiveness and social capital of Belarus and Ukraine. It made possible to propose ways to improve the use of existing social capital in the Republic of Belarus to ensure sustainable economic growth, including: ensuring uniform distribution of social capital in the country for various social horizons; improve the system, preventing the assignment of social capital accumulated at the societal level, the national bureaucracy; continue to develop partnerships society-state business.

\section{ВВЕДЕНИЕ}

В последние десятилетия в мире произошли радикальные социально-технологические изменения, радикальным образом трансформировавшие сущность рынка и рыночных отношений. Экономически развитые страны перешли к новому постиндустриальному обществу, опережающими темпами нарастает значение социальных и человеческих экономических ресурсов. Предлагаемая работа должна способствовать дальнейшему прогрессу экономической теории и методологии за счет исследования общего и особенного во взаимообусловленности экономической конкурентоспособности и социального капитала двух территориально и культурно близких постсоветских стран: Беларуси и Украины. При этом предполагается, что это будет способствовать дальнейшему политэкономическому осмыслению социально-экономической эффективности стратегий хозяйственного развития наших стран

\section{РЕЗУЛЬТАТЫ И ИХ ОБСУЖДЕНИЕ}

Общее и особенное в механизмах наращивания соииального капитала в Украине и Беларуси

Современная экономика перестает быть рыночной в понимании рынка первой половины XX века. Понимание этого в зарубежной экономической науке нашло свое выражение в возникновение большого количества концепций, претендующих на системное описание современного высокотехнологического общества, что привело к возникновению таких понятий, как «постиндустриальное общество», «информационное общество», «общество знаний», «технотронное общество», «сетевое общество», «экологический постиндустриализм» и т.д. Для большинства из названных подходов характерен технологический детерминизм. По нашему мнению особенностью нового этапа развития экономических отношений является радикальное изменение механизмов организации обмена между производителями и потребителями. Рыночный сегмент, длительное время господствующий в экономически развитых странах, становится периферийным. Для пострыночной экономики характерно наличие высокоэффективного промышленного производства, значительное увеличение доли сектора услуг в ВВП, дальнейшее увеличение значения знаний для развития экономики, развитие интернет-технологий и новые (пострыночные) формы конкурентной борьбы. Собственно говоря, важнейшим отличие рыночной экономики от пострыночной экономики и выступают новые общественнофункциональные технологии, применяемые в конкурентной борьбе. Прежде всего, это общественно-функциональные технологии, направленные на нелетальное разрушение социальных субъектов и ориентированные на противодействие этому разрушению.

В настоящее время общественно-функциональные технологии, направленные на нелетальное разрушение социальных субъектов, из сферы военно-политического противостояния естественным образом пришли в сферу политикоэкономической конкуренции. В литературе все чаще и чаще стали встречаться новые понятия «информационное оружие» и «информационная война», которые, в сущности, означают революцию не только в военном искусстве, но и в сфере компьютерно-информационных технологий. Часто за этим скрываются принципиально новые формы противо-

\footnotetext{
* Работа подготовлена в рамках выполнения гранта БРФФИ Г13К-051 «Теория влияния социального капитала на повышение конкурентоспособности реформируемых экономик».
} 
борства, в которых победа, «подавление противника» будет достигаться не с помощью классического (даже ядерного) оружия и традиционных способов ведения войны, а путем массированного использования информационного оружия. Многие аналитики технологически развитых стран считают этот вид оружия «решающим фактором владения современным миром». Национальные информационные ресурсы сегодня составляют все большую долю национального богатства в развитых странах. «Информационное оружие» сейчас называют «Троянским конем XXI века».

Появление информационного пространства привело к появлению желающих не только поделить это пространство, но и полностью контролировать и управлять теми процессами, которые протекают в рамках данного пространства. Для этого используется так называемое технико-ориентированное информационное оружие, которое подразделяется на то, которое направлено против компьютерных систем и способствует всяческой трансформации информации в пользу информационного агрессора. Оно выступает в таком случае в качестве средства уничтожения, искажения или хищения информации; средства преодоления систем защиты; средства ограничения допуска законных пользователей; средства дезорганизации работы технических средств, компьютерных систем. В отличие от техникоориентированного информационного оружия, информационное оружие как общественно-функциональная инновация представляет собой такой вид информационного оружия, который подвергает воздействию определенные группы социальных субъектов с целью навязывания им нужного манипулятора социально-экономического поведения.

Возникновение кибернетического пространства ознаменовало собой начало эпохи информационных войн. Это можно объяснить тем, что с появлением все более и более усовершенствованных компьютерно-информационных технологий, ведение информационной войны становится в разы быстрей и является более эффективным средством воздействия на социум. Так как хозяйствующий субъект уничтожается нелетально, а значит победа в информационной войне является «алгоритмически неразрешимой проблемой». Самая главная задача применения информационного оружия состоит в том, чтобы заставить противника направить имеющиеся у него средства, в том числе технические, против самого себя. Информационное оружие второго типа направлено против социальных субъектов и включает в себя «не силовые» методы борьбы такие, например, как сборка и разборка социального субъекта.

Для сборки и разборки социального (квази-социального) субъекта сегодня используется информационное оружие, под которым понимается средство ведения современной нелетальной войны. Оно обеспечивает идентификацию и поражение противника с помощью информационных концентраторов различных конструкций (традиционные СМИ, сетевые гипертекстовые концентраторы и т.п.); позволяет оказать влияние на социальный субъект, приводящее к блокированию его социальных действий (социальной активности); дает возможность эффективно перераспределять (переделить) материальные ресурсы (изменить отношения собственности) без нанесения повреждений самой собственности.

Если посмотреть на процессы сборки и разборки социального субъекта через призму категории социальный капитал, то становится очевидным, что в данном случае идет речь о процессах создания позитивного (с точки зрения того или иного социально-экономического субъекта) социального потенциала, т.е того социального капитала, который усиливает социальную силу, конкурентоспособность названного субъекта. С другой стороны, в современных межсубъектных отношениях также усиливается такой способ оптимизации условий реализации своих интересов, как разрушение социального потенциала конкурента.

Для того, чтобы показать общее и специфическое в механизмах наращивания социального капитала в Украине и Беларуси, необходимо определить соотношение в современной пострыночной экономике такой базовой политэкономической категории, как «потребление», с категорией «социальный капитал». Оговоримся, что, поскольку в свое время нами были раскрыты как соотношение категорий «социальный потенциал» и «социальный капитал», так и взаимообусловленность бытийных форм социального капитала, трудовых отношений, отношений собственности и экономических интересов (см.: С.Ю. Солодовников «Социальный потенциал Республики Беларусь: теория, методология, практика» [1]), то в рамках этого исследования нет гносеологической необходимости останавливаться на этой проблеме. Вместе с тем, поскольку ранее, повторяя серьезную методологическую погрешность современной экономической науки, нами не уделялось внимание символическому потреблению и символическим потребностям, а это, применительно к цели нашего исследования, понятия ключевые, то мы остановимся на этом подробно.

Ж. Бодрийяр справедливо заметил, что дальнейшего прогресса современной политэкономии в частности и экономической науки в целом необходимо, чтобы «анализ различающей социальной функции предметов и анализ политической функции идеологии, которая с ней связана» [2, с. 9], исходил «из одной абсолютной предпосылки: из отмены само собой разумеющегося рассмотрения предметов в терминах потребностей, отмены гипотезы первичности потребительной стоимости» [2, с. 9]. Поясняя свою теоретическую позицию, вышеназванный автор справедливо отмечает, что эмпирическая гипотеза, господствующая сегодня как в экономическом мэйнстриме, так и в ортодоксальном марксизме, «поддерживаемая очевидностью обыденной жизни, приписывает предметам функциональный статус, статус утвари, связанный с техническими операциями, относящимися к миру, и даже - тем самым - статус опосредования антропологических «природных» потребностей индивида. В такой перспективе предметы в первую очередь зависят от потребностей, приобретая смысл в экономическом отношении человека к окружающей среде. Эта эмпиристская гипотеза неверна. Дело обстоит совсем не так, словно бы первичным статусом предмета был прагматический статус, на который лишь затем накладывалась бы социальная знаковая стоимость - наоборот, фундаментальным является знаковая меновая стоимость, так что потребительная стоимость подчас оказывается просто ее практическим приложением (или даже простой рационализацией): только в такой парадоксальной форме социологическая гипотеза оказывается верной» [2, с. 9]. В рамках такого подхода важнейшей функцией обмена благ и предметов становится институционализация социальной иерархии. 
В свое время Т. Веблен доказал, что даже если первоначальной функцией подчиненных классов являлось производство, то все равно одновременно они выполняют функцию утверждения статуса Хозяина. Более того, в ситуации, когда подчиненные классы содержатся в праздности, эта функция становится единственной[3].

В контексте нашего исследования механизмов влияния на уровень накопления социального потенциала в обществе в целом и в отдельных его группах, а так же на формы его (потенциала) капитализации наиболее важным является не сама социально-классовая дифференциации, хотя это тоже важно, а «рассогласование между подразумеваемой мобильностью (стремлениями) и реальной мобильностью (объективными шансами социального продвижения)» [2, с. 21]. Как отмечал по этому поводу Ж. Бодрийяр: «эти стремления (подразумеваемая мобильность - С.С.) не являются свободными $<\ldots>$ они зависят от социальной наследственности и от уже достигнутого положения. Дойдя до определенного порога мобильности, они вообще исчезают- такова абсолютная покорность. В общем, они относительно нереалистичны: мы надеемся на большее, чем объективно в состоянии достичь, и в то же самое время относительно реалистичны: мы не даем разыграться нашему излишне честолюбивому воображению» [2, с. 21].

С этой точки зрения, подразумеваемые мобильностью (стремлениями) и реальной мобильностью (объективными шансами социального продвижения) различия между Беларусью и Украиной являются весьма существенными, что объективно влияет на механизмы наращивания социального потенциала и формы его капитализации как на уровне общества, так и на уровне других агрегированных социальных субъектов. Ранее нами уже было установлено, что специфическим свойством социального капитала является то, что совокупное количество «социального капитала» в обществе не является суммой «социальных капиталов» всех его субъектов. Это происходит не только потому, что существуют некоторые проявления социального капитала только на уровне всего социума, но и потому, что этот капитал социально-экономическими субъектами может использоваться не только в продукционных целях, но и с целью эгональной оптимизации своей социально-экономической жизненности, что вступает в противоречие с интересами других классов и групп, государства и социума. Для экономической оценки здесь можно использовать критерий КалдораХикса. В силу того, что социально-классовое расслоение в Украине является более глубоким, чем в Беларуси, социально-классовые противоречия в первой так же значительно более существенные, чем во второй. В современном обществе в отношениях между социальными классами (количество которых значительно больше, чем было в период господства индустриального производства, и, как правило, доходит до нескольких десятков) может наблюдаться как сотрудничество, так и борьба. Чем выше степень классового антагонизма, тем больше классы используют свой социальный капитал не для продукционных целей и поиска компромиссов, а для классовой борьбы. В первом случае (во многом характерном для белорусского социума) используются механизмы, содействующие наращиванию социального потенциала на уровне всего общества, что позволяет в процессе его капитализации успешно решать проблему устойчивого экономического роста, преодолевать экономические трудности. Иная картина в Украине, где любые экономические проблемы приводят к социальным взрывам и экономическим коллапсам, а частая смена правящих элит способствует непрекращающемуся переделу собственности (часто в латентных формах) и снижению уровня экономического развития. Низкая степень социального расслоения в Республике Беларусь и успешное использование социального капитала, накопленного на уровне общества, в немалой степени способствуют обеспечению высокого уровня реальных доходов населения.

Так, по данным исследования Института Гэллапа (США), доходы белорусов выше, чем у граждан России, Польши и стран Балтии. Опубликованные в начале декабря 2013 г. результаты исследования этого института о медианном уровне доходов в 131 стране мира показали, что Республика Беларусь находится на «32 месте среди исследовавшихся стран, не намного отстав от Португалии (30) и Словакии (31) и опередив такие страны, как Хорватия (33), Эстония (35) и Кипр (36)» [4]. Украина же находилась на 45-м месте. «Медианный уровень дохода - тот уровень, при котором 50\% представителей выборки имеют более низкий доход и 50\% - более высокий. Обычно отличается от среднего уровня дохода, который определяется сложением всех показателей дохода представителей исследуемой выборки и делится на количество ее представителей». [4] Следует также подчеркнуть, что Республика Беларусь превосходит Украину не только по уровню реальных и номинальных доходов населения, но и по уровню развития промышленности и сельского хозяйства. По производству промышленной продукции на душу населения Беларусь примерно в два раза опережает Украину. По производству сельскохозяйственной продукции разрыв еще более разителен. Так, например, «в Беларуси с населением около 9,4 млн. человек перерабатывается около 6 млн. тонн молока в год. В Украине с населением 48 млн. - около 4,5 млн. тонн» [5].

Названные различия оказывают влияние не только на механизмы наращивания социального капитала Беларуси и Украины, но и на механизмы противодействия такому способу межстрановой конкуренции, как сборка и разборка социальных субъектов (информационное оружие). Для разборки социума, т.е. для разрушения сотрудничества между субъектами, в него входящими, зарубежными манипуляторами общественного сознания сегодня часто используется противоречие между подразумеваемой мобильностью (стремлениями) и реальной мобильностью (объективными шансами социального продвижения). Под информационным оружием сегодня понимается средство ведения современной нелетальной войны (без физического уничтожения противника). Оно обеспечивает идентификацию и поражение противника с помощью информационных концентраторов различных конструкций (традиционные СМИ, сетевые гипертекстовые концентраторы и т.п.), позволяет оказать влияние на социальный субъект, приводящее к блокированию его социальных действий (социальной активности), позволяет эффективно перераспределять (переделять) материальные ресурсы (изменять отношения собственности) без нанесения повреждений самой собственности. При практическом применении информационного оружия создается некоторая виртуальная (идеальная) конструкция, воспринимаемая людьми как реальная. В результате дезориентированная часть населения начинает действовать не в целях реализации своих интересов, а в направлении, указываемом ими субъектом, который сумел успешно применить против них ин- 
формационное оружие. В нашем случае в качестве виртуальной (идеальной) конструкции выступает подразумеваемая мобильность. Людям внушают, что именно правительство их страны мешает тому, чтобы этот идеальный образ быстро стал реальным. И здесь не важно, что противоречие между подразумеваемой мобильностью (стремлениями) и реальной мобильностью (объективными шансами социального продвижения) - это явление, присущее всем социальноэкономическим системам без исключения. Для Манипулятора важнее, чтобы на уровне общества было накоплено мало социального капитала, тогда легче заставить людей разрушить свою экономическую систему, повысив тем самым конкурентные преимущества страны Манипулятора. Поскольку в Республике Беларусь намного выше уже накопленный социальный капитал на уровне общества, то наша страна может использовать его (капитал) для продукционных целей. В Украине же, поскольку уровень социального капитала на уровне общества низок, правительству, обществу в целом и хозяйствующим субъектам приходится нести значительные издержки не на развитие экономики, а на борьбу с «евро-майданами», т.е. на противодействие фактическому превращению Украины в колонию ЕС. Это позволяет сделать вывод, что механизмы наращивания социального капитала в Республике Беларусь и Украине коренным образом различаются.

Например, распад СССР, не соответствовавший экономическим интересам большинства населения Советского Союза (поскольку это неизбежно вызывало разрушение устоявшейся системы внутрисоюзного разделения и кооперации), тем не менее, был воспринят достаточно большим количеством советских граждан как позитивное событие. Главная субъектная причина этого - резкое снижение социального капитала на уровне общества. Усиление классовой, национальной борьбы и быстрый (часто криминальный) передел собственности, когда эгоистическое стремление увеличить свое, частное материальное богатство со стороны правящей элиты значительно снизило продукционную отдачу экономической системы общества. В Республике Беларусь и других постсоветских странах начинается экономический кризис, который сопровождается значительным абсолютным снижением ВВП на душу населения, отставанием по этому показателю даже от таких стран третьего мира, как Венесуэла, Аргентина и т.д., а также увеличением технологического разрыва с индустриально развитыми государствами. Резко ухудшились социальные и материальные условия жизни людей, у большинства из которых пропала вера в завтрашний день. Естественно, что это не могло не привести к сокращению продолжительности жизни и снижению ее качества.

Усиливающаяся в Беларуси классовая борьба, сопровождаемая массовыми выступлениями рабочего класса на фоне перманентной деградации экономической системы, и «грубые» (неумелые) попытки привнесения в страну рыночных институтов в формах, не соответствующих основным направлениям развития современной цивилизации, белорусской культуре и базовым институтам, привели к разочарованию в рыночных реформах большинства белорусов. Сформировавшееся у большинства населения к 1994 году неприятие либерально-рыночного пути социальноэкономического и политического развития, по которому пошла страна в начале 90 -х гг. обеспечило избрание Первого Президента Республики Беларусь А.Г. Лукашенко, что предопределило изменения социального и экономического курса страны. Новая экономическая стратегия в Республике Беларусь, начатая с приходом к власти А.Г. Лукашенко, заключалась в развитии социально-ориентированной модели рыночной экономики, когда государство стремится обеспечить всем своим гражданам определенные базовые социальные и экономические гарантии. Первоначально белорусская экономическая модель создавалась методом проб и ошибок (просто не было необходимой теоретической базы), что несколько повышало транзакционные издержки. Тем не менее, этот путь развития, адекватный сложившейся социально-экономической ситуации, коммунальной материально-технологической среде, белорусской культуре и базовым институтам общества обеспечил устойчивый рост белорусской экономики, улучшение ее структуры, повышение доходов большинства населения, возрастание социального капитала на уровне общества и иных агрегированных социальных субъектов.

Иначе постсоветская ситуация складывалась в Украине, которая не смогла выйти из этапа передела собственности и в которой обвальная приватизация обусловила деиндустриализацию страны. Неудачные либерально-рыночные эксперименты с собственностью на сельскохозяйственные земли дополнили картину развалом агро-промышленного комплекса и обнищанием крестьянства. Массово разочаровавшиеся в рыночных реформах украинцы не сумели сплотиться вокруг национального лидера, который мог бы воплотить в жизнь их социально-экономические классовые интересы. Такого лидера в Украине не было. В результате возрастание социального капитала в этой стране происходит на уровне классов, хозяйствующих субъектов, малых этнических групп, отдельных малых населенных пунктов и т.д. Названные субъекты, исходя из особенностей олигархической украинской модели, используют накопленный ими социальный потенциал только в своих частно-групповых интересах, усиливая этим классовые антагонизмы и препятствуя накоплению социального капитала на уровне общества. Как результат украинская экономика не эффективна, а население страны быстро разочаровывается в своих политиках.

Рассогласование между подразумеваемой и реальной мобильностями основывается на «неявной интерпретации социальными актантами объективных социологических данных: индустриальные общества предоставляют средним категориям населения определенные шансы на продвижение, но шансы сравнительно небольшие; социальная траектория за исключением отдельных случаев оказывается достаточно короткой, социальная инертность весьма ощутима, всегда остается возможность для регресса» [2, с. 21-22] Ж. Бадрияр писал, что в этом случае «создается впечатление, что: мотивация к восхождению по социальной лестнице выражает интериоризацию общих норм и схем общества постоянного роста; избыток стремлений по отношению к реальным возможностям выдает разбалансировку, глубокое противоречие общества, в котором «демократическая» идеология социального прогресса при случае вмешивается для того, чтобы компенсировать и переопределить относительную инертность социальных механизмов. Скажем иначе: индивиды надеются, потому что «знают», что могут надеяться, - они не надеются слишком, поскольку «знают», что 
это общество накладывает непроходимые препятствия на свободное восхождение, - и при этом они все-таки надеются чересчур, поскольку сами живут размытой идеологией мобильности и роста. Уровень их стремлений вытекает, следовательно, из компромисса между реализмом, питаемым фактами, и ирреализмом, поддерживаемым окружающей их идеологией, то есть из компромисса, который, в свою очередь, отражает внутреннее противоречие всего общества». $[2$, c. 22] В результате возникает «противоречие между рациональной экономической логикой и культурной классовой логикой» $[2$, с. 34$]$.

Очень откровенное и важное, с точки зрения нашего исследования, заявление по поводу европейских ценностей и проекта «Объединенная Европа» сделал Ж. Бодрийяр: «главной целью этой схемы интернациональной стратификации, проходящей под символом «Европы», является политическое осуществление национальной интеграции, свойственной каждой из рассматриваемых стран, причем осуществляется она не только со стороны потребления, но и со стороны стратификации» [2, с.47] При помощи этого проекта, позволяющего снизить степень накопления социального капитал и уровня самосознания низших классов «в статистической дихотомии, - отмечает Ж. Бодрийяр, - снимается старое разнообразие противоборствующих классов: их по-прежнему два, но между ними больше нет конфликта - два термина меняются на два полюса «социальной динамики». Следствием (и целью) такого тактического разделения оказывается нейтрализация крайних элементов и, следовательно, всякого противоречия, которое могло бы возникнуть из них в социальном плане: существует один-единственный модельный уровень (направляющая схема) и - все остальные. Перемешанные статистикой, они представляются в качестве просто населения, огромного среднего класса или тех, кто им может стать, класса, культурно уже подготовленного к роскошествам привилегированных классов. Нет больше никакого радикального неравенства между главой предприятия и служащим низового звена, поскольку последний, смешавшись в статистике со средними классами, видит, что ему уже доверен «средний» standing и обещан standing высших классов. На всем протяжении социальной лестницы никто не подвергается окончательному исключению». [2, с. 47-48]В Старой Европе, как отмечает Ж. Бодрийяр: «Вокруг обладания культурными и материальными благами организуется целая новая концепция классовой стратегии. Ценности и критерии потребления подвергаются мнимой универсализации лишь затем, чтобы еще успешнее привязать «безответственные» классы (то есть не обладающие властью решения) к потреблению и, тем самым, сохранить для руководящих классов исключительность их власти». [2, с. 49] Этот прием создает иллюзию объединения всех слоев «демократической» Европой.

Причем этот продукт манипулирования массовым сознанием (Проект «Объединенная Европа»), разборки социальных субъектов и принуждения таким образом последних к действиям не отвечающим не их личным, ни групповым, ни общественным социально-классовым интересам, широко используется европейскими правящими классами для экспорта своих общественно-функциональных технологий. Названный экспорт уже сегодня позволяет ЕС получать весомые экономические дивиденды не только в Европе, но и по всему миру. Главной характеристикой названных общественно-функциональных инноваций является то, что они, прежде всего, нацелены на снижение социального капитала на уровне общества. А вот здесь между Беларусью и Украиной обнаруживается большая разница. В Республике Беларусь накоплен значительный социальный потенциал на уровне общества, который успешно капитализируется (возникающие при этом транзакционные издержки иногда бывают достаточно большими, их можно и нужно минимизировать, но это не тема этого исследования), который позволяет успешно противостоять применению против нашей страны информационного оружия. В Украине, как нами уже отмечалось ранее, социальный капитал на уровне общества крайне низок и поэтому применение против этой страны информационного оружия причиняет украинскому социуму и экономике значительный ущерб. При этом традиционные механизмы накопления на уровне общества социального потенциала и его капитализации практически не работают.

Различия в механизмах наращивания социального капитала в Республике Беларусь и в Украине проявляются на микро-, мезо- и макро- уровнях. При рассмотрении этих различий напомним, что существует принцип оптимального соответствия накопленного и используемого социального капитала на вышеназванных уровнях. Суть названного принципа заключается в том, что количество накопленного и фактически используемого социального потенциала (т.е. социального капитала) на разных уровнях должны быть примерно равными. В противном случае нарушается гармония в экономической системе общества, агрегированные субъекты, обладающие большим социальным капиталом, начинают перераспределять экономические, социальные и иные ресурсы в своих интересах... как результат в обществе возрастают трансакционные издержки, снижаются темпы и качество экономического роста.

На микроуровне в Республике Беларусь созданы механизмы формирования условий роста социального капитала в результате государственной поддержки семьи, сохранения традиций, семейных ценностей. Обязательным условием для формирования и успешного развития этих механизмов является политическая, экономическая и социальная стабильность в обществе, которая есть в нашей стране. В Украине такой стабильности нет и после распада СССР никогда не было. Естественно, что механизмы накопления социального капитала в семьях, в условиях политической нестабильности, очень большой социально-классовой дифференциации и обнищания значительной части населения малоэффективны и значительно трансформированы психологией нищеты. Вместе с тем место реальной борьбы за оптимизацию своих экономических интересов (борьбы за социальную мобильность) для многих украинцев заняли образы врагов, которые мешают им хорошо жить и мечта о «европейском» рае, куда достаточно просто попасть.

Более стабильная политическая, экономическая, социальная и экологическая ситуация в Беларуси, по сравнению с Украиной, обусловливает более успешное использование таких форм возрастания социального капитала, как развитие системы образования; создание благоприятного психологического климата; развитие норм взаимности и доверия; рост имиджа белорусских коммерческих организаций, их руководителей и производимых ими товаров. Естественно, что и в Беларуси все это не протекает очень гладко, но для нашего исследования важнее тот факт, что накоп- 
ление социального капитала на микро-уровне в Республике Беларусь происходит намного быстрее и с использованием более разнообразных механизмов.

На мезоуровне отличие форм накопления социального капитала в Республике Беларусь от Украины заключается в значительно более высокой степени доверия бизнеса и населения к региональным властям (в конце 2013 г. -2014 г. неприятие региональной и центральной власти частью населения Украины даже вылилось в массовые беспорядки и вооруженное противостояние в регионах). В Беларуси более развиты механизмы формирования позитивного образа регионов, настраиваются формы поиска новых моделей взаимодействия бизнеса и власти, постепенно вырабатывается система взаимодействия бизнеса, населения и власти на основе доверия и т.д.

На макроуровне (на уровне общества) в Беларуси сформирован и достаточно эффективно работает такой важный механизм накопления и капитализации социального потенциала, как доверие к Президенту и органам государственного управления, во многом предопределяемый тем, что А.Г. Лукашенко является харизматическим лидером и воспринимается большинством населения нашей страны как высшая инстанция, к которой можно обратиться в поисках справедливости и защиты. Это способствует эффективному функционированию в нашей стране механизмов обеспечения законности и правопорядка, укрепление общенационального согласия. Сегодня в экономической науке является общепризнанным факт связи между усредненным показателем доверия и национальным доходом. Например, Р. Инглхард считает, что эта связь составляет 0,56 [6]. В Украине нет общепризнанного национального лидера и всем ее президентам приходилось и приходится лавировать между множеством групп, вступающих между собой в открытую конфронтацию, не редко сопровождаемую крайними формами гражданского неповиновения и насилия. Естественно, что это делает невозможным продукционное использование и такого важного условия наращивания социального капитала на уровне общества, как законность и правопорядок.

Принциипы и механизмы влияния экономической конкурентоспособности Беларуси и Украины на процесс накопления ими социального капитала

Необходимость взаимосвязанного рассмотрения понятий экономическая конкурентоспособность страны и социальный капитал страны в процессе изучения экономического положения той или иной страны в современном мире сегодня уже ни у кого не вызывает сомнений. Обосновывается подобная необходимость наличием целого ряда совпадающих элементов в структуре и функциях указанных понятий:

1) выражаемые при помощи данных понятий явления относятся к числу общественных институтов. К примеру, в рамках функциональной концепции конкуренции последняя рассматривается в качестве общественного института, значимость которого «проявляется в следующих моментах: рынка;

- ресурсы общества используются более эффективно, неэффективно работающие производители вытесняются с

- существует стимул к разработке и внедрению инноваций, техническому обновлению бизнеса, оперативному реагированию на требования потребителей;

- при конкурентной рыночной структуре ни один хозяйствующий субъект не может оказать решающего влияния на рынок (необоснованно увеличить затраты, цены и т.д.)» [7]. Соответственно, под экономической конкурентоспособностью, по мнению М. Портера, понимается свойство товара, услуги, субъекта экономических отношений выступать на рынке наравне с присутствующими там аналогичными товарами, услугами или конкурирующими субъектами рыночных отношений [8].

В свою очередь, социальный капитал нередко рассматривается в качестве ядра гражданского общества [9], т.е. он выступает в роли ключевого, базового института такого общества. Кроме того, отдельные исследователи включают в состав социального капитала не только различные социальные институты, но и другие общественные явления: «Элементами социального капитала выступают социальные связи и пути, по которым они создаются: доверие, обеспечивающее действие членов общества как единого целого; нормативы и правила; укрепляющие доверие институты, обеспечивающие функционирование общества; позитивные цели членов группы или общества» [10].

Если учесть, что все общественные «институты призваны минимизировать трансакционные издержки» [11, с. 70], то можно сделать вывод о сходных функциональных характеристиках явлений, раскрываемых с помощью понятий экономическая конкурентоспособность страны и социальный капитал страны;

2) выражаемые при помощи данных понятий явления имеют общие тесные связи с другими экономическими явлениями (например, с феноменом модернизации). С одной стороны, модернизация национальной хозяйственной системы проводится, прежде всего, с целью повышения экономической конкурентоспособности производимой в ее рамках продукции на внешних рынках. С другой стороны, «природа ассоциированной жизни - того, что некоторые ученые назвали социальным капиталом, является ключевым фактором местных способностей к обучению и модернизации» $[11$, с. 74$]$. Более того, отдельные исследователи прямо связывают «местные способности», т.е. социальный капитал страны, с ее экономической конкурентоспособностью, обходясь без посредства понятия модернизация: «Конкурентоспособность национальной экономики напрямую зависит от уровня знаний и компетенций населения как субъекта все усложняющегося производства, от которого требуются не только базовые знания в сфере науки и техники, но и способность к непрерывному совершенствованию профессиональных и технических навыков, и как потребителя, воспринимающего и использующего в практической деятельности информацию о действии, безопасности и эффективности новых продуктов и технологий. Отсутствие таких способностей у определенной части населения может стать фактором, сдерживающим создание и распространение новых технологий» [12]. 
Если факт наличия тесных взаимосвязей между понятиями экономическая конкурентоспособность страны и сочиальный капитал страны является для большинства исследователей достаточно очевидным, то сами принципы и механизмы влияния экономической конкурентоспособности той или иной страны на процесс накопления ею социального капитала изучены сегодня в значительно меньшей степени. Именно этим определяется необходимость формулирования концептуальных подходов к выявлению и описанию указанных принципов и механизмов. На наш взгляд, сегодня можно выделить два основных концептуальных подхода при рассмотрении названных выше понятий и явлений.

Существо первого концептуального подхода заключается в необходимости учитывать базовые принципы и механизмы повышения конкурентоспособности той или иной страны в процессе выявления более специфических принципов и механизмов влияния повышения конкурентоспособности данной страны на рост ее социального капитала. В частности, к числу базовых принципов повышения экономической конкурентоспособности страны необходимо отнести следующие теоретические конструкты: 1) принцип свободной конкуренции; 2) принцип эффективного использования имеющихся конкурентных преимуществ (ресурсов); 3) принцип формирования благоприятной институциональной среды для развития экономики и др. При этом, как правило, каждый такой принцип реализуется в экономической практике посредством использования специфического механизма повышения конкурентоспособности страны.

К примеру, специфика механизма реализации принципа эффективного использования имеющихся конкурентных преимуществ (ресурсов) определяется тем, каким базовым ресурсом располагает данная страна (масштаб экономики; богатые природные ресурсы; развитая наука; высокообразованное население; высокотехнологичная промышленность; выгодное географическое положение; большой объем накопленных знаний (патентов, лицензий, всевозможных «ноу-хау», технологий и проч.); развитая национальная инновационная система; высокий уровень интеграции национальных экономических акторов в систему мирохозяйственных связей (международные инновационные сети, ТНК, интеграционные союзы и объединения); богатое культурное прошлое и проч.).

Основу второго концептуального подхода составляет понимание того факта, что использование далеко не всех базовых принципов и механизмов повышения экономической конкурентоспособности страны реально содействует росту ее социального капитала. Так, использование в качестве базового принципа повышения экономической конкурентоспособности страны принципа свободной конкуренции, который реализуется посредством механизма максимальной либерализации экономики и снижения до минимального уровня роли государства в экономической жизни страны, как показывает международный опыт, не способствует росту социального капитала страны, поскольку жесткоконкурентные отношения между экономическими субъектами («война всех со всеми») препятствуют налаживанию интеграционных хозяйственных связей в обществе (за исключением связей, возникающих в процессе хозяйственных и торговых слияний и поглощений, а также в процессе формирования стратегических альянсов и т.п. корпоративных структур). Кроме того, минимизация функций государства в экономике (вплоть до выполнения им роли «ночного сторожа») отрицательно сказывается на развитии социальной сферы страны, в рамках которой, в основном, и нарабатывается ее социальный капитал. Частные компании и ТНК развивают, в лучшем случае, только свою, корпоративную социальную сферу.

Наконец, в зависимости от макроэкономических показателей народнохозяйственного развития той или иной страны эффективность влияния конкретных принципов и механизмов повышения конкурентоспособности данной страны на рост ее социального капитала может варьировать в очень широких пределах. Например, наличие в стране развитой науки максимально способствует взаимообусловленному росту ее конкурентоспособности и социального капитала только в том случае, если в экономике данной страны сформировались следующие условия: а) крупные высокотехнологические компании; б) развитая национальная инновационная система; в) высокий уровень востребованности народным хозяйством новейших научных достижений.

С целью выявления сходств и различий в применяемых Украиной и Беларусью принципах и механизмах повышения конкурентоспособности их экономик, а также в степени влияния таких принципов и механизмов на рост социального капитала данных стран целесообразно поочередно рассмотреть практику использования названными странами базовых принципов и механизмов повышения экономической конкурентоспособности страны. В частности, анализ особенностей реализации принципа свободной конкуренции и механизма, обеспечивающего его применение в повседневной хозяйственной практике Украины и Беларуси, показал, что использование данного принципа и связанного с ним механизма реализации в указанных странах имеет существенные отличия. К примеру, в Беларуси «формирование конкурентных отношений, создание транспарентных, соответствующих международным стандартам правил осуществления бизнеса» [13] относятся отдельными исследователями (например, Ю.А. Ясинским) к перспективным направлениям институциональной политики нашего государства.

Более того, в монографии Л.А. Гуцаленко теоретически обосновывается свободообразующий характер конкуренции: «Свобода и конкуренция - понятия синонимичные, переходят друг в друга... Социальность свободы состоит в том, что она не может ограничиться какой-либо одной сферой деятельности человека. Если ее не было, скажем, в экономической деятельности (безраздельная монополия государственной собственности при авторитаризме), то ее не могло быть и в области политических отношений и далее - науке, искусстве, морали, религии. В свою очередь, ее наличие в этих сферах предполагает свободу интеллектуального, состязательного самовыражения человека, включая право на риск и готовность личности нести ответственность за свободный выбор нестандартных, инновационных альтернатив действия перед другими людьми, законом, обществом. В этом, собственно, и заключается реальная, а не декларированная свобода: гарантия выбора целей, способа действия и распоряжения достигнутым благом. Таким образом, свободообразующая роль конкуренции состоит в гарантированной обществом возможности субъектов и социаль- 
ных групп свободно самоопределяться в средствах, способах деятельности, на альтернативной основе обмениваться ее результатами» $[14$, с. 23$]$.

В полном соответствии с декларируемой свободой конкуренции, по мнению Л.А. Гуцаленко, осуществляются и практические мероприятия по созданию в Беларуси конкурентной ситуации: «Правительство Республики Беларусь, учитывая высокую насыщенность промышленного комплекса страны предприятиями-монополистами, прилагает усилия к их разукрупнению и тем самым созданию конкурентной ситуации. Это сложный процесс перестройки внутренних и внешних хозяйственных связей между производителями, поставщиками и потребителями. К 2005 году преобразовано в общей сложности 4100 предприятий республики. Среди них 543 (13,2\%) объекты промышленности, 292 $(7,1 \%)$ - строительства, 81 (2\%) - транспорта и связи, 1521 (37,1\%) - торговли и общественного питания, 459 (11,2\%) - бытового обслуживания населения, 763 (18,6\%) - агропромышленного комплекса, 441 (10,8\%) - прочих отраслей народного хозяйства. Количество работающих на реформированных предприятиях - 958,9 тыс. человек или более $22,3 \%$ от общей численности занятых в экономике республики» [14, с. 171-172].

В то же время в Беларуси в последние годы «на смену рыночно-конкурентной доктрине развития уверенно приходит интеграционная парадигма экономической науки и практики» [15]. На деле подобный поворот совсем не означает полного отказа от реализации принципа свободной конкуренции. Просто среди белорусских экономистов все более ширится понимание той простой истины, что «сегодня отнюдь не либеральная, конкурентная, до предела «атомизированная» рыночная экономика, а наоборот, только высоко интегрированный и при этом активно управляемый «зримой рукой» государства единый народнохозяйственный комплекс может быть глобально конкурентоспособным перед лицом могучих западных суперкорпораций» [16]. Поэтому не жесткоконкурентная «война всех со всеми» внутри страны, а максимальная интеграция и объединение всех белорусских производителей в единую госкорпорацию «Беларусь» может повысить глобальную конкурентоспособность на внешних рынках как белорусской экономики в целом, так и отдельных ее хозяйствующих субъектов.

По справедливому замечанию белорусского исследователя В.В. Новика, «глобальная конкурентоспособность достигается стратегией активного роста, углублением кооперации и взаимодействия многих компаний. Сегодня в индустриально развитых странах у крупных фирм, для того чтобы продолжить успешную деятельность на международном уровне, нет иной альтернативы взаимовыгодной совместной деятельности. Отсюда следует, что общепринятая состязательная экономика на очередном этапе развития начинает являть определенную тенденцию к превращению в экономику сотрудничества, ведущую к эффективности труда более высокого порядка» [17]. Нет необходимости пояснять, что такая совместная деятельность многих десятков и даже сотен белорусских предприятий, как никто и ничто иное, порождает устойчивые и весьма многочисленные социальные связи между ними, а значит, способствует росту социального капитала Беларуси.

Кстати, сам факт постепенного превращения основательно дезинтегрированного в начале 1990-х гг. народнохозяйственного комплекса страны в единую государственную корпорацию «Беларусь» сегодня признают как сторонники официального стратегического курса Республики Беларусь [18], так и его откровенные противники. Один из таких противников, А. Горных, пишет по этому поводу следующее: «Несмотря на всю свою общинно-деревенскую риторику, Беларусь строит свою модель корпоративного капитализма, в котором единственной и неповторимой корпорацией является государство» [19]. Аналогичную стратегию и тактику выживания в современном жесткоконкурентном мире используют и многие западные страны: «В новых условиях государства Запада начинают вести себя подобно гиперкорпорациям, плавно переходя к достаточно своеобразному новому протекционизму, ориентированному не столько на ограничения в доступе для тех или иных товаров на национальную территорию, сколько на создание там гораздо более выигрышных условий для крупномасштабной экономической деятельности» [20]. Описанный белорусский вариант реализации принципа свободной конкуренции и механизма его имплементации в народнохозяйственную практику можно назвать, вслед за российским экономистом С. Губановым, «максимальной системной конкурентоспособностью» [21].

Несколько иной вариант реализации указанного принципа и механизма его применения в народнохозяйственной практике наблюдается в экономике Украины. Сохранив все недостатки жесткоконкурентной, либеральной «войны всех против всех», проявившиеся в экономической практике Украины еще в начале 1990-х гг., ее руководство усугубило эти недостатки государственным «крышеванием» откровенно монополистических, олигархических структур, рассматривая данное «крышевание» в качестве средства конкурентной борьбы. Аналогичные высказывания о государственном «крышевании» отечественных олигархических структур можно найти и у российских экономистов: «К сожалению, искомого рода интереса к ГЧП (государственно-частному предпринимательству. - C.C.) у российских предпринимателей сегодня, как правило, нет. И дело здесь в том, что главным инструментом конкурентной борьбы для них являются не технологические и организационные модернизационные подвижки, а «крышевание» со стороны обладателей тех или иных «государевых дожностей» (данный «топ-секрет» сплошь и рядом раскрывают и предприниматели, и сами высшие должностные лица государства)» [22].

Таким образом, противоестественное для нормальной рыночной экономики сочетание предельной «атомизации» экономических акторов на нижнем уровне конкурентной экономической борьбы с откровенным государственным лоббированием интересов олигархических структур на верхнем уровне такой конкурентной борьбы привело к полной дезинтеграции народнохозяйственного комплекса данной страны. Отмеченная дезинтеграция наиболее отчетливо проявилась в полной рассогласованности действий производственных структур Украины и тех исследовательских организаций, которые обеспечивают научное сопровождение деятельности производственных структур: «Сложилась парадоксальная ситуация: научные (особенно научно-технические) учреждения медленно «умирали» из-за 
отсутствия спроса на их продукцию со стороны производителей, а последние прекращали деятельность из-за отсутствия новых идей и разработок для производства конкурентоспособной продукции. А все потому, что власть оказалась неспособной обеспечить координацию их деятельности, построить грамотную научно-техническую и инновационную политику как на центральном, так и на региональном уровнях» [23].

Результатом такой своеобразной, «самостийной» реализации принципа свободной конкуренции в народнохозяйственной практике Украины стало дальнейшее уменьшение величины социального капитала в различных отраслях украинской экономики. Как справедливо заметил украинский экономист А.С. Попович относительно отсутствия значимой корреляции между величиной украинского ВВП, его наукоемкостью и объемом социального капитала украинской науки, «если наукоемкость ВВП в нашей стране на протяжении последних 20 лет обнаруживает устойчивую тенденцию падения, независимо от того, падает или растет ВВП, то это может служить убедительным доказательством того, что социальный капитал отечественной науки не только не растет, но даже падает. Во всяком случае - та составляющая этого символического капитала, которая определяется доверием к ней, пониманием ее значения для страны депутатами, премьерами, президентами и министрами» [24].

Столь же различное наполнение в Беларуси и Украине получила практическая реализация принципа эффективного использования имеющихся у данных стран конкурентных преимуществ (ресурсов). Беларусь ввиду отсутствия у нее мало-мальски значимых природных ресурсов (за исключением месторождений калийных удобрений) сделала ставку на формирование и использование такого специфического экономического ресурса, как инновации. Причем в большинстве случаев - это общественно-технологические, а не технико-технологические инновационные решения. Белорусский исследователь Д.Ф. Рутко обосновывает данный выбор Беларуси следующим образом: «В современных условиях конкурентоспособность товаров, предприятий и стран все в большей степени определяется способностью национальной экономики генерировать и внедрять новые технологии. Инновации становятся фактором, способным существенно влиять на формирование национальной конкурентоспособности. Так, при анализе наиболее конкурентоспособных государств обращает на себя внимание тот факт, что лидеры по этому показателю являются одновременно и лидерами в технологической области. Удельный вес инноваций в общем индексе конкурентоспособности государств составляет от $1 / 3$ до 1/2. При этом по мере достижения высшей инновационной стадии развития все больший удельный вес в обеспечении конкурентоспособности имеют инновации» [25]. В пользу правильности сделанного руководством Республики Беларусь выбора в пользу инновационного развития национальной экономики свидетельствуют и высказывания ведущих западных экономистов: «На Западе вопрос «Нужны инновации или нет?» уже давно не стоит, поскольку ответ слишком очевиден: без нововведений и постоянного развития любая, даже очень успешная сегодня компания останется за бортом конкуренции уже завтра» [26].

При этом Республика Беларусь определилась не только с ключевым ресурсом повышения своей экономической конкурентоспособности (инновации), но и с механизмом формирования и использования данного специфического ресурса. Как свидетельствуют белорусские экономисты Т.Э. Амбрусевич и В.И. Кудашов, сегодня органам государственного управления и подавляющему большинству хозяйствующих субъектов Беларуси хорошо «известен и механизм, обеспечивающий конкурентоспособность, - это создание благоприятных условий для активной инновационной деятельности» [27]. С этой целью в нашем государстве реализуется уже вторая Государственная программа инновационного развития Республики Беларусь на 2011-2015 гг. (ГПИР 2011-2015). Первая такая программа (ГПИР 2006-2010) была реализована в 2006-2010 гг.

В частности, из аналитического доклада «О состоянии и перспективах развития науки в Республике Беларусь по итогам 2011 года» (Мн., 2012) можно получить адекватное представление о масштабах инвестиционных затрат в рамках выполнения указанной ГПИР 2011-2015: «Общие инвестиционные затраты, связанные с реализацией инновационных проектов ГПИР в 2011 г., составили 15832,8 млрд руб. (157,5\% от плана)... Инвестиционные затраты по источникам финансирования всех инновационных проектов распределились следующим образом: собственные средства 4759,6 млрд руб. (30\%); иностранные инвестиции, кредиты - 4672,2 (29,5\%); кредиты белорусских банков - 5256,0 млрд руб. (33,2\%); средства республиканского бюджета - 1022,6 млрд руб $(6,5 \%)$; средства местного бюджета - 122,5 млрд руб. $(0,8 \%) \ldots$ Объем производства инновационной продукции составил 1258,6 млрд руб., создано и (или) модернизировано 2543 рабочих места» [28].

Приведенные выше цифры убедительно свидетельствуют о том, что руководство Республики Беларусь достаточно последовательно формирует благоприятные условия для активной инновационной деятельности отечественных предприятий. В пользу такого вывода можно привести и иные аргументы: 1) из года в год растет численность субъектов инновационной инфраструктуры белорусской экономики (технопарков, бизнес-инкубаторов, технологических кластеров, центров трансфера технологий, спин-офф предприятий, стартапов и др.). В настоящее время число таких субъектов превысило уже сотню наименований [29]; 2) стремительно развивается созданный в Беларуси Парк высоких технологий (за 2006-2012 гг. его внешнеторговый оборот превысил 1 млрд долл. [30, с. 56]). Последнее стало возможным благодаря беспрецедентным налоговым льготам, которые Парк высоких технологий получил от белорусского государства: «Парк высоких технологий имеет специальный правовой режим и льготные условия хозяйствования. Его резиденты освобождаются от уплаты налога на прибыль, на добавленную стоимость на внутреннем рынке и на недвижимость. Предусмотрены преференции и при исчислении подоходного налога с физических лиц» [30, с. 55].

Приведенные выше данные об инвестиционных затратах Республики Беларусь на реализацию инновационных программ и проектов, формирование инновационной инфраструктуры и льготное налогообложение отдельных субъектов такой инфраструктуры дают нам основания сделать вывод о том, что руководство нашего государства учитывает при разработке своей стратегии модернизации и инновационной политики богатый опыт Европы, Индии и Китая в этом вопросе. 
В отличие от советского общества, в котором наличие большего социального капитала обеспечивало его обладателям больший доступ к общественным и потребительским благам, тем самым выполняя в командноадминистративной экономике редистрибутивную и стратифицирующую роль, в развитой рыночной экономике накопленный обществом социальный капитал выполняет интегративную функцию, придавая данному типу экономики черты единой хозяйственной корпорации: «Рынок можно рассмотреть как корпорацию отдельных торговцев, каждый из которых располагает социальным капиталом, величина которого определяется количеством взаимосвязей на рынке» [31]. Более того, «при достаточном запасе социального капитала общество может частично замещать государство в основной сфере полномочий последнего - предоставлении общественных благ, принимая на себя ответственность за содержание объектов инфраструктуры, поддержание общественного порядка и пр. Социальный капитал делает возможным саморегулирование отраслей экономики, позволяя сократить масштабы государственного регулирования; аналогичным образом корпоративная социальная ответственность снижает потребность в участии государства в охране окружающей среды, трудовых отношениях, контроле качества продукции и т.д.» [32]. Таким образом, связь между социальным капиталом и экономической конкурентоспособностью страны в развитой социально ориентированной рыночной экономике является весьма значимой, способствуя формированию гражданского общества (самоорганизации общественности), которое берет под свой контроль действия государственных чиновников.

Вот почему приоритет, отдаваемый органами государственного управления в Украине традиционной сырьевой экономике, в которой доминирующую роль играют олигархические структуры, а не «новым социальноэкономическим пространствам», где большую роль играет самоорганизация общественности, самым негативным образом сказывается на величине социального капитала данной страны. В этом отношении весьма показателен следующий вывод украинского экономиста И.А. Булкина: «Объём инновационных расходов на душу населения в Беларуси намного (в 3,07-5,64 раза) превосходит украинские значения. Централизованная экономика оказалась адекватнее задачам инновационного развития, нежели рыночно-олигархическая. Примечательны не только масштаб превышения - в разы (что компенсирует возможные ошибки наблюдения, которые обычно имеют меньшую размерность), но и то, что превышение имело место на всём интервале наблюдения. Что особенно важно - пропорция сохранилась и в условиях мирового финансового кризиса: если в 2008 г. уровни белорусских и украинских удельных затрат соотносились как 3,07:1, то в 2012 г. - уже как 3,89:1, а рекордное значение в соотношении датируется 2011 г. Таким образом, не опровергая тезис о восприимчивости уровня инновационной активности в Беларуси к внешнеэкономическому негативу (объем затрат в 2012 г. в постоянных ценах сократился против 2007 г. на 33,2\%), мы утверждаем, что политика стабилизации в Украине удалась в меньшей мере (соответствующее сокращение - 48,3\%). Кроме того, максимальное соотношение стран по удельным расходам на НИОКР составило 1,983 в пользу Беларуси (достигнуто в 2011 г.; в 2002 г. только 0,787). Конечно, далеко не все инновации базируются на достижениях науки и техники, и далеко не весь фронт научного поиска имеет производственную направленность, однако сравнение косвенно свидетельствует в пользу более высокой эффективности внедрения научно-технических результатов в промышленности Беларуси, нежели Украины» [33].

С рассотренным выше принципом эффективного использования имеющихся у Беларуси и Украины конкурентных преимуществ (ресурсов) тесно связан принцип формирования благоприятной институциональной среды для развития экономики данных стран. Практическая реализация данного принципа в народнохозяйственной практике Беларуси и Украины тоже существенно отличается. В Беларуси раньше, чем в Украине, поняли и начали использовать в экономической практике преимущества «мягких» факторов повышения конкурентоспособности страны. Хотя приоритет в использовании таких факторов принадлежит все-таки не Беларуси, а наиболее развитым западным странам: «По оценке специалистов экспертной корпорации «Всемирный экономический форум» уже в 1992 году конкурентные преимущества страны с развитой экономикой лишь на 15\% зависели от традиционных («жестких») показателей, таких как объем ВВП, уровень инфляции, состояние торгового баланса. На 85\% международное положение страны зависит от «мягких» факторов конкурентоспособности. К их числу относятся мотивация труда, степень образованности и квалификации кадров, выработка системы ценностей на производстве» [34].

Тем не менее, белорусское руководство вовремя осознало преимущества таких «мягких» факторов повышения экономической конкурентоспособности страны и начало последовательно, из года в год, наращивать потенциал этих факторов в отечественной экономике:

1) повышать мотивацию труда на отечественных предприятиях. К примеру, с 2000 г. по 2013 г. годовые денежные доходы на душу населения Беларуси по среднегодовым курсам национальной валюты к доллару США выросли с 698 долл. до 5174 долл. (для сравнения: за этот же период денежные доходы на душу населения Украины по среднегодовым курсам национальной валюты к доллару США выросли с 361 до 2247 долл.) [35, с. 153];

2) повышать уровень образованности белорусского населения. К примеру, численность студентов в высших учебных заведениях Беларуси с 2000/2001 учебного года по 2013/2014 учебный год увеличилась с 282 тыс. чел. до 395 тыс. чел., т.е. в 1,4 раза (для сравнения: за этот же период численность студентов в высших учебных заведениях Украины увеличилась с 1403 тыс.чел. до 1724 тыс. чел., т.е. в 1,2 раза) [35, с. 169, 171];

3) формировать систему ценностей на производстве. К примеру, чем иным, как не созданием своей, белорусской системы производственных и организационных ценностей, можно объяснить тот факт, что в 2013 г. (по сообщениям мировых информационных агентств) отмечалось следующее: «В Беларуси с населением около 9,4 млн. человек перерабатывается около 6 млн. тонн молока в год. В Украине с населением 48 млн. - около 4,5 млн. тонн». [5] Эту ситуацию отдельные украинские предприниматели (например, генеральный директор компании "Инфагро" Василий Винтоняк) комментировали следующим образом: «Наращивание объемов переработки молока - это четкий план для 
молочной отрасли страны, поставленный их президентом (Президентом Республики Беларусь А.Г. Лукашенко - С.С., В.Щ.). И они (белорусские производители молочной продукции - С.С., В.Щ.) активно ищут рынки сбыта, альтернативные российскому». [5] При этом конкурентоспособность белорусской «молочки» настолько выше украинской (при том, что в Украине намного выше естественное плодородие почвы, более теплый климат и т.д.), что для защиты свое внутреннего рынка украинские предприниматели в 2013 г. предлагали ввести квотирование белорусской молочной продукции на их внутреннем, украинском рынке. Пытались даже инициировать антидемпинговое расследование, хотя понимали бесперспективность такой акции. Как видно из сказанного, сами украинские специалисты в области сельского хозяйства признают более высокую конкурентоспособность белорусской модели хозяйствования.

Приведенные выше сравнительные данные по развитию «мягких» факторов повышения конкурентоспособности в Беларуси и Украине (в совокупности такие «мягкие» факторы можно назвать человеческим капиталом), дают основания Л.А. Гуцаленко, автору монографии «Социология конкуренция» (2007г.), сделать следующий вывод: «Если брать общие показатели доли человеческого капитала в национальном богатстве, то в этом отношении Беларусь выглядит предпочтительнее других стран СНГ. Здесь его доля достигает 55,4\%, тогда как в Украине - 53,1\%, в России 50,9\%. Следовательно, можно сказать, что один из основных, если не базовый фактор возможности повышения конкурентоспособности Республики Беларусь у нас не хуже, а даже несколько лучше, чем у наших соседей» [14, с. 99]. Следует напомнить, что по сравнению с 2007г., когда была написана цитируемая монография Л.А. Гуцаленко, доля человеческого капитала в структуре национального богатства Украины существенно снизилась как в результате продолжающейся гражданской войны в ряде регионов. Так и усиливающейся миграцией высококвалифицированных кадров за пределы страны, в том числе и из тех регионов. Которые формально в вооруженном противостоянии не участвуют.

\section{ВЫВОДЫ}

Таким образом, сегодня очевидно, что практическая реализация базовых принципов и механизмов повышения экономической конкурентоспособности Украины и Беларуси оказывает самое непосредственное влияние на динамику их социального капитала. Причем в Украине реализация указанных принципов и механизмов ведет к снижению величины социального капитала, а в Беларуси, наоборот, ведет к росту социального капитала, что объясняется коренным отличием избранных данными странами макроэкономических моделей хозяйствования: либерально-олигархической модели - в Украине и социально ориентированной рыночной экономики с сильным государственным регулированием - в Беларуси.

\section{ЛИТЕРАТУРА}

1.Солодовников С.Ю. Социальный потенциал Республики Беларусь: теория, методология, практика. - Мн.: Беларус. навука, 2009. - 303 с.

2.Бодрийяр Ж.. К критике политической экономии знака / пер. с фр. - М.: Библион-Русская книга, 2003.

3. Veblen lb. The Theory of the Leisure Class. - Paris, 1969.

4.Исследование Института Гэллапа: доход белорусов выше, чем в России, Польше и странах Балтии // Электронные ресурс, режим доступа 18.12.2013 http//ntws.tut.by/economics/379411.html.

5.Украина хочет ограничить импорт белорусской «молочки» // [Электронные ресурс] - Режим доступа: http//news.tut.by/economics/369418.html Дата доступа: 13.04.2015.

6.Inglehard R/ Culture Shift in Advanced Industrial Society. Princeton, N. J. Princeton University Press, 1990.

7. Маркова В.Д., Кузнецова С.А. Стратегический менеджмент: понятия, концепции, инструменты принятия решений: Справочное пособие. - Новосибирск: НГУ, 2010. - С. 57.

8.Портер М. Конкуренция / Пер. с англ. - М., 2010. - С. 57.

9.Глинская У. Социальный капитал в теоретической перспективе социологии // Вестник Брестского государственного технического университета. - 2010. - № 6. - С. 97.

10. Федотов Л.Н. Роль модернизации в преодолении коррупции // Философские науки. - 2011. - № 11. C. 150 .

11. Хершберг Э. Глобальная реструктуризация, знания и обучение // Вопросы экономики. - 2004. - № 8.

12. Шувалова О.Р. «Образ» науки: восприятие населением результатов научной деятельности // Форсайт. - 2007. - № 2. - С. 54.

13. Ясинский Ю., Тихонов А. Россия и Белоруссия: сравнительный анализ социально-экономической динамики // Экономист. - 2010. - № 6. - С. 56.

14. Гуцаленко Л.А. Социология конкуренции / Под науч. ред. А.Н. Данилова. - Мн.: Право и экономика, 2007.

15. Байнев В. Интеграция вместо конкуренции // Наука и инновации. - 2010. - № 5. - С. 55.

16. Байнев В.Ф. Экономикс как псевдонаучная научно-образовательная парадигма // Новая экономика. 2012. - № 1. - C. 7 .

17. Новик В.В. Повышение конкурентоспособности машиностроительных предприятий путем реструктуризации (корпоратизация и оптимизация рынков). - Мн., 2009. - С. 24.

18. Кизима С. ТНК «Беларусь» // Беларуская думка. - 2009. - № 8. - С. 52-57. 
19. Горных А. Вечное возвращение по-белорусски // Белорусский формат: невидимая реальность: сб. науч. тр. / Отв. ред. А.Р. Усманова. - Вильнюс: ЕГУ, 2008. - С. 186.

20. Неклесса А.И. Ordo quadro: пришествие постсовременного мира // Мегатренды мирового развития / Под ред. М.В. Ильина, В.Л. Иноземцева. - М.: Экономика, 2001. - С. 146.

21. Губанов С. Системный выбор России и уровень жизни // Экономист. - 2011. - № 11. - С.11.

22. Гринберг Р., Сорокин Д. Как переломить складывающиеся негативные макротренды? // Российский экономический журнал. - 2014. - № 1. - С. 18.

23. Палагин А.В., Соловьев В.П., Сенченко В.В. Международный трансфер технологий с использованием современных информационно-коммуникационных технологий: возможности для Украины // Международный научный конгресс по развитию информационно-коммуникационных технологий и формированию информационного общества в Украине (17-18 ноября 2011 г., г. Киев). (в печати). - С. 3.

24. Попович А.С. Предисловие редактора // Малицкий Б.А. Социальный капитал науки: оценка и пути наращивания. - К.: Феникс, 2013. - С. 6.

25. Рутко Д.Ф. Инновации как условие эффективной интеграции страны в глобальное мирохозяйственное пространство // Проблемы управления. - 2005. - № 1. - С. 65.

26. Дертниг Ш. Эра инноваций в России // Эндрю Дж.П., Сиркин Г.Л. Возврат на инновации: практическое руководство по управлению инновациями в бизнесе / Пер. с англ. - Мн.: Гревцов Паблишер, 2008. - С. 12.

27. Амбрусевич Т.Э., Кудашов В.И. Нематериальные активы как источник конкурентных преимуществ организации // Экономика и управление. - 2011. - № 2. - С. 41.

28. О состоянии и перспективах развития науки в Республике Беларусь по итогам 2011 года: Аналитический доклад / Под ред. И.В. Войтова, А.М. Русецкого. - Мн.: ГУ «БелИСА», 2012. - С. 212.

29. Внешнеэкономический фактор в стратегии инновационного развития России и Беларуси / под ред. И.В. Войтова. - Мн.: ГУ «БелИСА», 2012. - С. 114.

30. Ц Цепкало В., Старжинский В., Павлова О. Ведущий кластер ИТ-индустрии // Наука и инновации. 2013. - № 4 .

31. Коулман Дж. Капитал социальный и человеческий // Общественные науки и современность. - 2001. № 3. - C. 125 .

32. Полищук Л., Меняшев Р. Экономическое значение социального капитала // Вопросы экономики. 2011. - № 12. - С. 51-52.

33. Булкин И.А. Динамика инновационных затрат как показатель роста конкурентоспособности и экономической безопасности Украины и Беларуси // Межакадемический совет по проблемам развития Союзного государства. Вып. 5. Интеграция и вопросы безопасности Союзного государства / Под ред. С.М. Дедкова, В.К. Егорова. - Мн.: Центр системного анализа и стратегических исследований НАН Беларуси, 2013. - С. 223-224.

34. Супрун В.А. Интеллектуальный капитал: Главный фактор конкурентоспособности экономики в XXI веке. - 2-е изд. - М.: Книжный дом «ЛИБРОКОМ», 2010. - С. 6.

35. Содружество Независимых Государств в 2013 г. Краткий сборник предварительных статистических итогов / Статкомитет СНГ. - М., 2014. - С. 153.

Статья поступила в редакичию 13 июля 2015 года. 